\title{
An Evaluation of the Undergraduate TEFL Program in Iran: A Multi- Case Study
}

\author{
Amin Karimnia \\ Asst. Prof., Department of English, Fasa Branch, Islamic Azad University, Iran \\ aminkarimnia@yahoo.com
}

\section{Elham Kay}

Department of English, Qeshm International Branch, Islamic Azad University, Iran

Kay@yahoo.com

The purpose of this study is to assess the quality of Islamic Azad University TEFL program at B.A. (undergraduate) level in Iran. To do so, five IAU branches were selected through cluster sampling. Within each branch selected, twenty senior students were randomly sampled as the participants of the study. In addition to the students, five professors who were selected through accidental sampling participated in this study, too. Using Stufflebeam's (2002) CIPP model, the data were gathered through a researcher-made questionnaire. This model incorporates four main segments including the evaluations of context, input, process and product. Concerning the students' responses, the results of the study revealed that most of the students agreed that the teaching materials had to be revised along with the TEFL program itself. The students also believed that learning strategies must be more concentrated on. In addition, they believed that professors have to focus on teaching specific courses. Concerning the results of the semi-structures interviews, the professors mostly pointed out that considerable reform has to be implemented in TEFL curriculum design. The interviewees also stated that the pedagogical approaches commonly used over the past decades suffered from shortcomings which have to be overcome.

Key Words: TEFL, curriculum design, CIPP model, program evaluation, undergraduate

\section{INTRODUCTION}

Teaching English as a Foreign Language (TEFL) is one of the sub-fields of English language studies all over the world. This academic field of science focuses on the frameworks, procedures and methods through which one can learn English as a foreign language. In addition, it refers to teaching English to students whose first language is not English. TEFL is usually used in the student's own country, either within the state school system or privately regulated schools or classrooms (after regular school hours or with a tutor). TEFL teachers may be native or non-native speakers of English (Brown, 1980). At an academic level, several methods of teaching have been used to teach TEFL

DOI: $10.12973 / \mathrm{iji} .2015 .827 \mathrm{a}$ 
courses at universities. These courses, however, need to be designed carefully to affectively serve learners and students. In other words, the collective objective of these courses is to help students learn how to read, write, listen and speak English as a Foreign Language (EFL).

A basic question, however, remains about the efficiency of these educational programs and contents. In other words, researchers may seek to discover whether these programs meet the desired ends promised or expected (Karimnia \& Salehi Zadeh, 2007; Karimnia $\&$ Mahjoobi, 2013). One method of program evaluation of these courses, from a general point of view, refers to "a structured process that creates and synthesizes information intended to reduce the level of uncertainty for stakeholders about a given program or policy" (McDavid \& Hawthorn, 2006, p. 3). It involves a careful collection of information about a program or some of its aspects to make necessary decisions (McNamara, 2002). Evaluation is a widely used tool for assessing a program's efficiency in public, non-profit, and private sector organizations around the world (Foroozandeh, Riazi \& Sadighi, 2008).

The main aim of the present study is to unravel the quality of teaching courses of TEFL at B.A. level (undergraduate) at different Islamic Azad University branches in Iran. This study evaluated the TEFL curriculum in B.A. program implemented at nine major universities in Iran approved by the Official Curriculum developed in 1987 in light of Stufflebeam's CIPP Model (2002) of program evaluation. English language professors, administrators, students, and so on will find the findings, implications and suggestions of the study useful.

\section{REVIEW OF LITERATURE}

\section{Curriculum Design}

A curriculum is an important part of TEFL classes. It provides a focus for the class and sets goals for the students (Drakos, 2005). A curriculum also gives the student a guide as to what they will learn and how much progress they made when the course is over (ibid.).Although many large English academic centers have set a curriculums for their teachers, the smaller and more abundant English centers tend to allow their teachers to decide how the classes are conducted. This latter method, as liberal as it may sound, can lead to difficulties for those who have little or no experience in teaching English.

\section{The Evaluation of Teaching Programs}

The practice of valuating teaching programs dates back to the 1960s in the United States when the Great Society social programs were introduced by the Kennedy's and Johnson's Administrations. The Great Society refers to a set of domestic programs proposed or enacted in the US by President L.B. Johnson. The reform program sought two main goals, namely, the elimination of poverty and racial injustice (Rossi, Lipsey and Freeman, 2004). Having conducted an overall evaluation, some of the programs were eliminated or had their funding reduced, while many of them including Medicare, Medicaid, and federal education funding, continued up to the present. In effect, program evaluation is so essential a process that some key organizations in the United States and 
Canada have developed theoretical frameworks to implement proper program evaluations (GAO, 1998).

As for timing, program evaluation may be scheduled from different perspectives. Henning (1987) classifies the different types of evaluation into prior-to-program implementation, during-program delivery, and following-program execution. Similarly, McDavid and Hawthorn (2006) divide it into ex-ante evaluation (done before program implementation) and ex-post evaluation (done after program implementation). As for purpose, which is closely related to timing, McNamara (2002) identifies three major types of evaluation, namely, goals-based, process-based, and outcomes-based with sample questions pertinent to each type.

Along the same lines, Rossi et al. (2004) identify five dimensions of program evaluation including (a) needs assessment, which examines the nature of the problem; (b) program theory, or the program's conceptual framework; (c) process analysis, which is concerned with how the program is implemented; (d) the impact of evaluation, which determines the effect of the program; and (e) cost-benefit or cost-effectiveness analysis, which assesses the efficiency of the program in terms of the costs and benefits.

Based on insights gained from developing the curriculum for Language Preparation for Employment in the Health Sciences and a review of the literature on ESP, Gatehouse (1998) proposed a theoretical support for ESL instructors in developing ESP curricula for ESL contexts. In the late 1999, Gatehouse (ibid.) was asked to develop a contentbased curriculum for a ten-week course for a select group of immigrants living in Ottawa, Canada. The curriculum consisted of two distinct phases: language delivery and employment awareness. Although the employment awareness phase (independently developed and delivered by Local Agencies Serving Immigrants) was an integral component of the program, the focus of the paper was on insights gained from the language-delivery phase.

\section{Key Issues in EFL Curriculum Design}

Cummins (1979) proposed a dichotomy between basic interpersonal communication skills (BICS) and cognitive academic language proficiency (CALP). Situations in which individuals use BICS are characterized by contexts that provide relatively easy access to meaning. However, CALP use occurs in contexts that offer fewer contextual clues.

Having developed and taught the curriculum for Language Preparation for Employment in the Health Sciences, Gatehouse (1998) believes that there were three abilities necessary for successful communication in a professional target setting. She added a third skill or ability to Cummins' (1979) theory in order to complete the ESP picture.

Basic interpersonal communication skills is the ability to use the particular jargon characteristic of that specific occupational context. The second is the ability to use a more generalized set of academic skills, such as conducting research and responding to memoranda. Within the health science group, this was related to understanding a new culture. Cognitive academic language proficiency is the ability to use the language of everyday informal talk to communicate effectively, regardless of the occupational 
context. Examples of this include chatting over coffee with a colleague or responding to an informal email message.

\section{Materials Development}

Gatehouse (1998) asks a vital question, "do ESP textbooks really exist?"This is the question that Johns (1990) has asked. One of the main dilemmas Johns presented was that "ESP teachers find themselves in a situation where they are expected to produce a course that exactly matches the needs of a group of learners, but are expected to do so with no, or very limited, preparation time" (ibid., p. 91).

Many ESL instructors and/or ESP developers, in the real world, are not given enough time for needs analysis, materials research, and materials development. There are many texts which claim to meet the needs of ESP courses. Johns (1990) asserts that no ESP text could live up to its name. He suggests that the only real solution is to make available a resource bank of pooled materials to all ESP instructors. The only difference between this resource bank and the one available in every educational setting (i.e. teachers' filing cabinets) is that this one is expected to include cross-indexed doable, workable, and content-based resources.

\section{Empirical Background}

Foroozandeh, Riazi and Sadighi (2008) conducted a large-scale study designed based on Stufflebeam's CIPP Model (2002) to evaluate the TEFL curriculum in M.A. program implemented at 9 academic settings in Iran following the Official Curriculum developed in 1987. The participants of the study included 68 M.A. students, 34 instructors, and 9 administrators. The data were collected through three questionnaires, interviews, and written responses. Two course-based questionnaires including 3-point and 5-point Likert type items as well as one open-ended question for students and instructors were developed based on the Official Curriculum.

The questionnaire included a 5-point Likert scale as well as two open-ended questions. The three questionnaires shared 23 items on the program's work plan. Interviews were also conducted with 18 instructors and 30 students. The data were analyzed using both quantitative and qualitative procedures, but due to the large volume of analyses, the paper reported only the results of the qualitative analysis in detail. To validate and interpret the findings, the same procedures were discussed with about 10 M.A. students and 2 instructors. The findings generally revealed that: (a) there was no consensus among the participants regarding the overall aim of the program; (b) the curriculum implemented was partially compatible with the Official Curriculum; and (c) the participants generally felt the need for revision in the official curriculum, reform in program delivery, and consideration of the screening system.

In a study conducted by Halim Ulaş, Epcacan and Kocak (2011), the researchers aimed to assess Turkish language teaching program of the second grade primary school in terms of critical thinking skills.To document the examination method, a qualitative research method was employed in the research. Giving information on the general structure and content of Turkish language teaching program, the authors reviewed related issues. These observations were classified under the titles of critical thinking 
skills. In the reviewed Turkish language teaching program, 158 among the total of 228 under the fields of "reading, listening/following, speaking, writing, learning, and grammar" were found to be intended for critical thinking skills. It was further ascertained that these gains were intended more for "application" and "analysis" skills than those of critical thinking.

In another empirical work carried out by Breen and Jenkins (2002), undergraduate and postgraduate students drawn from 8 different disciplines at a UK university were asked to participate in structured discussions of the effects of lecturer research activity upon student learning. Both samples showed a substantial preponderance of positive over negative comments. In both groups, the frequency of positive comments about lecturer research activity increased as the quantity and quality of research in their discipline increased (as measured by Research Assessment Exercise [RAE] ratings). In the undergraduate samples, the frequency of negative comments about research also increased with RAE rating, while among postgraduates it diminished. Undergraduates and postgraduates showed consistency in articulating the benefits of lecturer research, including enhanced knowledge currency, credibility, competence in supervision and enthusiasm/motivation. Both groups were also consistent in identifying reduced availability of lecturers, competition with teaching, and curriculum distortion as negative effects of lecturer research activity. In addition to the "generic" benefits of research identified by both groups, postgraduates emphasized the importance of the salience (interest, relevance and utility) of lecturer research in the content of their learning. Implications of the findings for pedagogic research and educational policy are then discussed.

In their "Language curriculum development Research at University Level", Towell and Tomlinson (1999) provided an account of an example of curriculum development over a 10 -year period. Motivated by a belief in the value of comprehensible input, the purposeful teaching of language in a context, and the need for a variety of text types linked to the development of interpersonal skills, the authors devised a model for taskbased curriculum design, and together with many of their colleagues, they have implemented and evaluated it on two occasions. The use of diaries and questionnaires on the first occasion enabled a number of lessons to be learned and these helped considerably in creating a second application where the testimony of the student population through a detailed questionnaire shows the success of the operation.

\section{Stufflebeam's Model}

There are several approaches to evaluation and the purposes that it would serve. Stufflebeam's "Context, Input, Process, Product" (CIPP) Model was first developed in 1966. This model is a basic and frequent approach in both education and Human Resource Development (HRD) settings. Stufflebeam's improved model released in 2002 in the form of a checklist is explained briefly as follows (Stufflebeam, 2002, pp. 1-10):

Context evaluation: What needs to be done? It assesses needs, assets, and problems within a defined environment;

Input evaluation: How should it be done? It assesses competing strategies and the work plans and budgets of the selected approach; 
Process evaluations: Is it being done? They monitor, document, and assess program activities;

Product evaluation: Did it succeed? In the 2002 checklist, the Product Evaluation part is divided into impact, effectiveness, sustainability, and transportability evaluations as follows: (a) Impact evaluation assesses a program's reach to the target audience; (b) Effectiveness evaluation assesses the quality and significance of outcomes; (c) Sustainability evaluation assesses the extent to which a program's contributions are successfully institutionalized and continued over time; and (d) Transportability evaluation assesses the extent to which a program could successfully be adapted and applied elsewhere.

Figure 2.1.provides an overview on the CIPP model proposed by Stufflebeam (2002) in a tangible way:

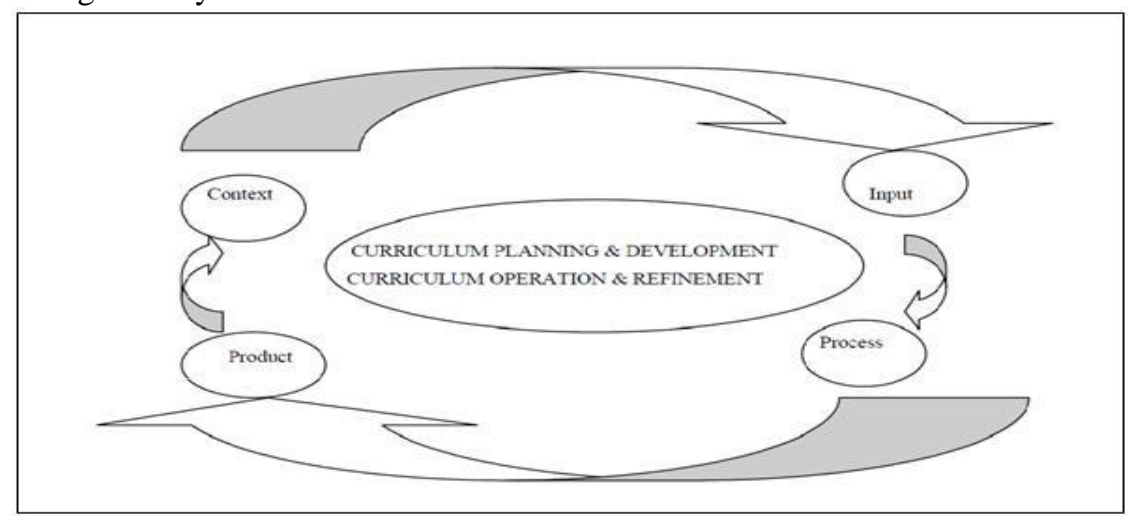

Figure 1: The CIPP Model by Stufflebeam (2002)

Based on this model, a program will go on as it is, if the evaluation checklist confirms its efficiency in achieving its objectives. Otherwise, there would be the need for innovation in case shortcomings are observed.

\section{METHOD}

\section{Participants}

One hundred Iranian senior students of TEFL studying at different branches of IAU were selected as the participants of the present study. The students were selected through cluster sampling. Table 3.1. provides a demographic overview on the participants of the study, as follows:

Table 1: $\quad$ The Participants of the Study

\begin{tabular}{ll}
\hline IAU Branch & Number of Participants \\
\hline Shiraz Branch & 20 \\
\hline North Tehran Branch & 20 \\
\hline Isfahan (Khorasgan Branch) & 20 \\
\hline Isfahan (Shahreza Branch) & 20 \\
\hline Abadeh Branch & 20 \\
\hline Total & 100 \\
\hline
\end{tabular}




\section{Instrumentation}

A researcher-designed questionnaire was given to the participants of the study. The questionnaire was composed based on Stufflebeam's (2002) CIPP model, with the purpose of investigating several related aspects of teaching. The rating of the questionnaire was based on 5-point Likert scale. The questionnaire contained 8 items to be considered by the participants of the study. These items were related to the four main elements of the model in question in pairs. The questionnaire aimed at investigation the students' attitudes toward (a) the goal of the program, (b) the official and the implemented curriculum (c) the teachers' teaching and evaluation methods, (d) the efficiency of the screening system, the weak points, and suggestions for improvement. The validity of the questionnaire was confirmed by three professors. In addition, the reliability of it was calculated through Cronbach's alpha, which was observed to be 0.881 , showing the high reliability of the questionnaire.

As the model used was designed to investigate the quality of the TEFL curriculum design at different IAU branches in Iran, the questionnaires distributed to the students could not serve as a suitable touchstone by themselves. As a result, a set of semistructured interviews with some TEFL professors were carried out by the researcher while dealing with the act of data collection.

\section{Data Collection Procedures and Analysis}

After distributing the questionnaire among the participants, they were asked to read the questions carefully and fill in the required data. The questionnaire asked the students' attitudes towards the program, as well as their general impression of the program quality and how it could be improved in terms of the courses, instructors, and the method.In addition, five professors participated in the interview. They talked about their teaching and evaluation methods as well as issues in program administration, and gave general comments on the quality of the program and its efficiency in detail. Interviews took between 15 to 25 minutes depending on the informants' time.

The data gathered were analyzed and elaborated on using 5-point Likert scale. The related descriptive statistics were then presented through charts, tables, figures, etc. However, the qualitative side tended to have a more significant role in this section due to the nature of the study.

\section{FINDINGS}

The present study aimed at assessing the quality of TEFL program at B.A. level. This was done with a special reference to IAU branches in Iran. There were eight questions posed to be answered during the process of the research program. Based on Stufflebeam's (2002) CIPP model, each question investigated a specific evaluation element introduced within the model in question. The researcher came up with 800 answers upon which 796 were valid responses. In this section, each of the evaluation categories and the related findings as related to the students' responses are presented.

\section{Students' Responses}




\section{Context Evaluation}

This evaluation tool assesses what needs to be done. It also assesses "needs, assets, and problems within a defined environment" (Stufflebeam, 2002, pp. 1-10). In this regard, two choices were posed as followings:

1.The need for practicality in TEFL modules has often been neglected

2. Some fundamental issues like giving lectures have often been dismissed within the IAU branches at B.A level of TEFL.

As the results of the study revealed, 59 participants strongly agreed, 12 agreed, 26 disagreed, 1 strongly disagreed, and 2 had no idea about the first item relating to context evaluation introduced by Stufflebeam (2002). Concerning the second item, these numbers shifted to $3,21,43,26$, and 1 , respectively. Figure 2. illustrates the sum of each item:

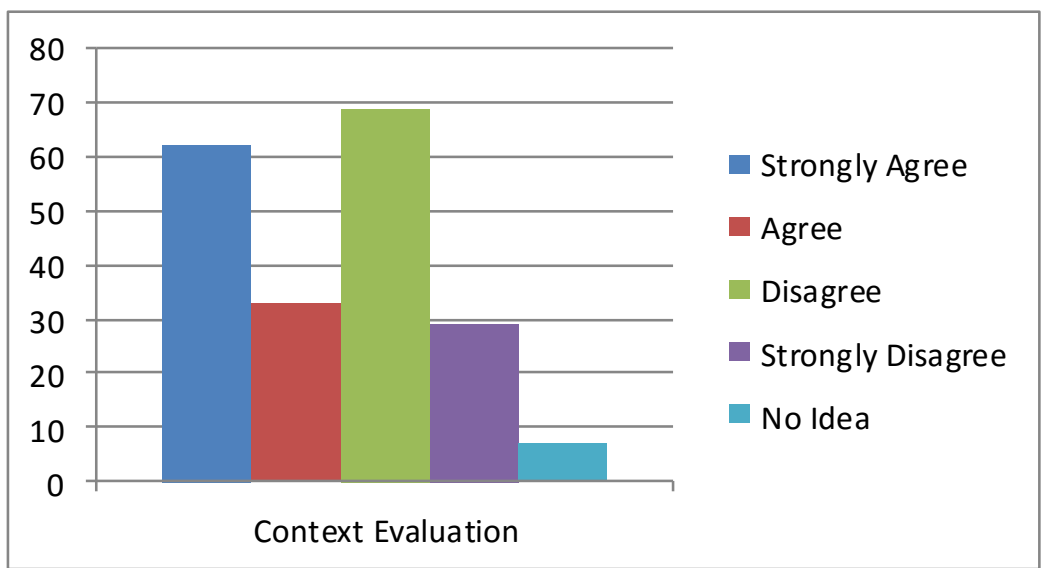

Figure 2: Student's Responses to Context Evaluation (N of Valid Responses= 200)

Input Evaluation

The input evaluation tool assesses "competing strategies and the work plans and budgets of the selected approach" (Stufflebeam, 2002, pp. 1-10). In this regard, two choices were suggested, which are presented as follows:

1.I think the TEFL program at B.A level in IAU is sufficient, but the materials need to be revised.

2.I think the TEFL program at B.A level in IAU needs revisions.

Concerning the first item posed in this regard, 69 participants were in strong agreement, 12 in agreement, 9 in disagreement, and 4 in strong disagreement. However, 6 participants checked the no idea part. Concerning the second question in input evaluation part, these figures were found to be $64,10,21,3$, and 2, respectively. Figure 3. shows the descriptive sum of each item: 


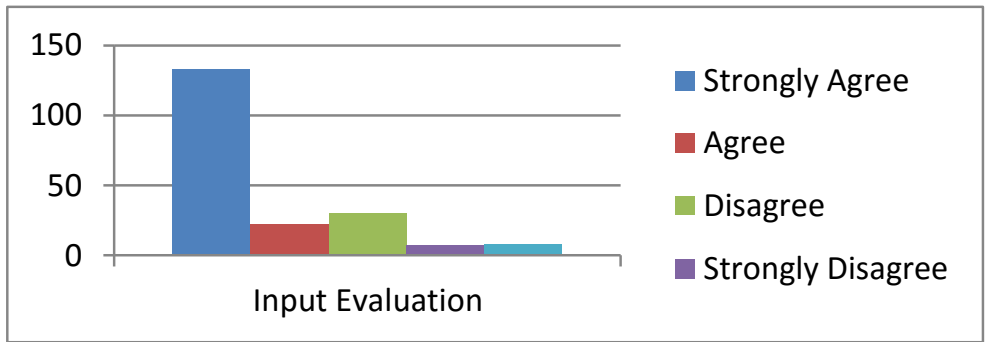

Figure 3: Student's Responses to Input Evaluation (N of Valid Responses= 200)

Process Evaluation

Process evaluation tools "monitor, document, and assess program activities" (Stufflebeam, 2002, pp. 1-10). Concerning this tool, the two choices were as follows:

1.Students play an important role in a TEFL program success. However, I believe that they are mostly not acquainted enough with special issues such as learning strategies, effective reading strategies, etc.

2.In my opinion, as TEFL professors are not usually assigned to teach specific courses, students are faced with difficulties.

Regarded as the third item to be checked by the students, process evaluation achieved most of its grades in agreement. In other words, concerning the first question of this section, 52 participants showed to be in strong agreement. Twenty seven (27) students showed to be in agreement. While 15 students were in disagreement, only 3 of them showed strong disagreement. The number of students without any idea on the item in question was 1 for this part.

Concerning the second question of this evaluation item, the number of participants were $63,15,12,7$, and 2 respectively. It is important to mention that the number of valid responses for this item was 197, as 3 responses had not been checked at all. Thus, these were not considered valid responses (see Cohen, et al., 2007). Figure 4. illustrates the sum of each item related to process evaluation:

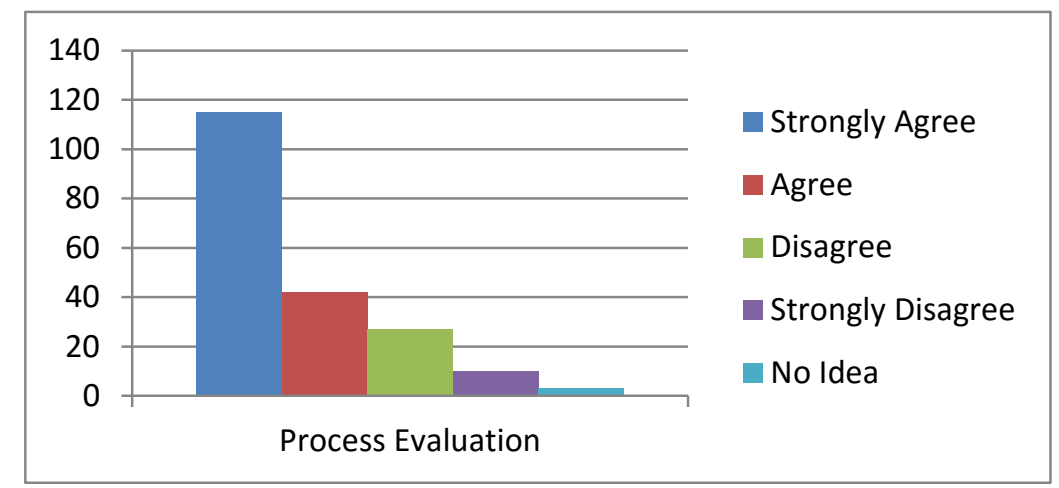

Figure 4: Student's Responses to Process Evaluation ( $\mathrm{N}$ of Valid Responses= 197) 


\section{Product Evaluation}

Finally, product evaluation tools were used to assess the extent to which the program was successful. This is sub-divided into four categories, namely, impact, effectiveness, sustainability, and transportability evaluations (Stufflebeam, 2002, pp. 1-10). These questions were posed to delve into this evaluation tool:

1.I am satisfied with the materials being taught at B.A. level in IAU branches.

2.I am satisfied with the TEFL program at B.A. level in IAU branches.

As for the last evaluation item, the results of the study showed mostly disagreements of the participants. In fact, only 9 participants strongly agreed and 4 of them agreed with the item under investigation. Ten (10) of them disagreed with the first item of the product evaluation, while 76 students strongly disagreed. Only 1 student had no precise idea about the first item. Concerning the second question posed for the product evaluation item, the number of students changed to $1,15,13,68$, and 2 respectively. It is important to note that the number of invalid responses for the product evaluation item was 1 . In other words, 199 responses were valid ones to be considered during the process of data analysis (Cohen et al., 2007).

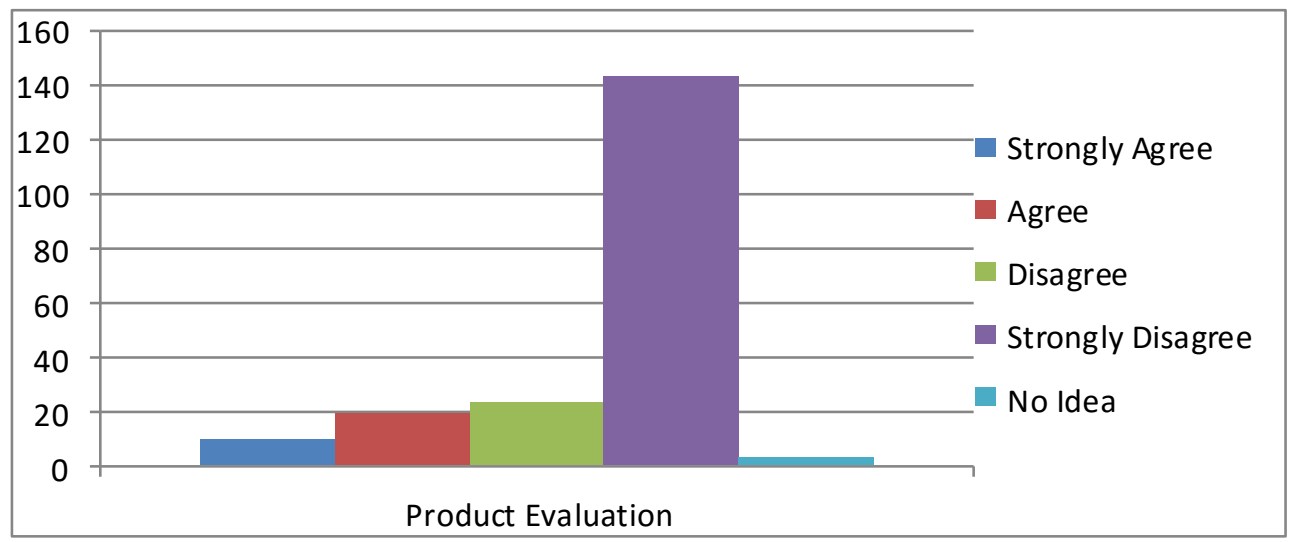

Figure 5: Student's Responses to Product Evaluation (N of Valid Responses= 199)

\section{Semi-Structured Interviews}

As mentioned earlier, in order to obtain more reliable data on the TEFL program evaluation at B.A. level in IAU branches, a set of semi-structured interviews were conducted. In this regard, five professors were selected through accidental sampling. After having interviews, the four main categories suggested by Stufflebeam (2002) were discussed. The results of these interviews are presented in the following section.

\section{Context Evaluation}

The professors interviewed mostly believed that a lot needs to be done in the realm of TEFL curriculum design. This statement was made with special reference to IAU TEFL 
syllabus at B.A. level. In their opinion, what mostly has been neglected in terms of practicality in TEFL is sometimes related to the students themselves. In other words, they are the ones who, in most of the cases, do not show any interests in the practicality of their major.

In addition, they mostly believed that basic foundation of TEFL is related to practice. Giving lectures during a class time, for instance, is the core segment of a TEFL classroom. However, students mostly tend to dismiss these important roles of a student.

\section{Input Evaluation}

The interviewed professors were mostly in agreement that the selected pedagogical approaches might have been facing shortcomings during the past decades. Three of the professors interviewed were the faculty member of universities with more than twenty years of teaching experiences.

One of the professors, however, had a different idea on the adopted approach and believed that it would suffice. According to this interviewee, the system itself, along with the people involved are among those variables which control the approach in an academic context like a university.

\section{Process Evaluation}

Professors mostly put the main blames on the students. Learning strategies, for instance, were among the issues pointed out by two of them, which in turn, have always been neglected by different intakes of the universities. One of the professors claimed that students expect the professors to teach them all the materials needed, while they roughly try to learn essential issues in learning, which is crucial for teaching in future.

None of the professors agreed with the second part of the process evaluation. In other words, they all believed that a professor has the capability of teaching any course related to his/her major. On TEFL, for instance, they all claimed that teaching methodology, phonology, research, etc. are among the courses related to their experts. However, three of them agreed that some courses like linguistics, translation and literature had better be taught by the experts. Still, they had no problems with these courses being offered to them.

\section{Product Evaluation}

Finally, the interviewees ideas were asked as related to the product evaluation, which assesses the extent to which the program succeeds. As mentioned earlier, this tool is further sub-divided into four categories, namely, "impact, effectiveness, sustainability, and transportability evaluations" (Stufflebeam, 2002). All five professors were in agreement with the urgent need to renew the TEFL program at B.A. level within the context under study. In their opinion, there is the need for more nascent topics to be discussed. Computational courses (e.g., computational linguistics, teaching, phonology, research, etc.) were among those emphasized. One of the professors believed that the pace of TEFL must go hand in hand with the rising pace of technology in the global 
context. Although each country could have its own TEFL program meeting to the needs of its people, it must not be taken for granted.

Concerning the materials being taught, the professors had more positive ideas. According to the interviewees, these are among the topics chosen by the professors, although some topics are suggested by the university. Thus, they would be able to choose the topic they wish. In their opinion, there are often some criteria for such choice. The materials had better be first-hand within the academic context. However, one of the professors believed that some older materials which are taught are more useful.

\section{DISCUSSION}

This study sought to assess the quality of TEFL program in Iran by focusing on IAU official curriculum design. The basic foundation of the present study was similar to those carried out by Foroozandeh et al. (2008), in which the researchers reported part of a large-scale study designed based on Stufflebeam's CIPP Model (2002). They tried to evaluate the TEFL curriculum in M.A. program, while the present work aimed at B.A. level. While Foroozandeh et al. (ibid.) studied 9 major universities in Iran with regard to the Official Curriculum developed in 1987, the present study focused on 6 IAU branches. The results of Froroozandeh et al. (ibid.) support the findings of the present study. In fact, the former one came up with the fact that participants generally felt the need for: (a) the official curriculum's revision, (b) reform in program delivery; and (c) reconsidering the screening system.

The method of the study has some similarities with that used by Keyvanfar (1999), who evaluated the Undergraduate Translation Program in 7 branches of the Islamic Azad University in Tehran and four neighbouring cities. The results of her study revealed a general pattern of improvement in language proficiency and translation ability, but the program was not successful with regard to the program's objectives including gaining general proficiency in all four skills of English, and gaining translation skills and having adequate opportunities to actually translate different kinds of texts.

Rahmani (2007) replicated the same study carried out by Keyvanfar (1999) in six branches of the Islamic Azad University in Tehran and the same four neighbouring cities. Findings revealed general success of the program despite a number of problems to be considered by the policy-makers. This supports the results of the present study, which in contrast to the problematic issues pointed out by the students and professors, reported some improvements, too. Keyvanfar's (1999) and Rahmani's (2007) studies are "valuable as the first steps toward recognizing the necessity of evaluation in the Iranian higher education context" (Foroozandeh et al., 2008, p. 79).

In comparison with Foroozandeh et al.'s (2008) methodology, in the present work which used Stufflebeam's (2002) CIPP model, the study addressed both goals-based and process-based questions in an academic context and was of a during-program delivery type. The only difference was that the product, i.e., the program's success, was evaluated in terms of impact, effectiveness, sustainability, and transportability of the program in the study carried out by Foroozandeh et al. 


\section{CONCLUSION}

This study sought to assess the quality of TEFL program in Iran. To do this, the opinions of both students and professors were investigated. As for the responses made by students, the results of the study pointed that most of the students strongly agreed with making revisions in terms of the materials being taught at IAU branches in Iran. This means that most of the students studying at IAU branches are not satisfied with the materials due to different reasons. The need for making revisions also addressed the TEFL program itself. The students also believed that learning strategies are among the items which should be focused on more and more by them. In addition, the students believed that professors have to focus on teaching specific courses.

Concerning the results of the semi-structures interviews, the professors mostly believed that a considerable revisions should be made in the TEFL curriculum design. Thus, it could be concluded that the program and the materials are two core segments which need urgent revisions. In addition, they believed that although the basic foundation of TEFL is related to practice, this core segment is usually neglected by the students themselves. The concluding remarks of this item are related to the role of the students. In other words, they have to boost the TEFL program output with making efforts on focusing on learning strategies, and so on. The interviewees also believed that the selected pedagogical approaches might have suffered from shortcomings over the past decades.

\section{REFERENCES}

Brown. H. D. (1980). Principles of language learning and teaching.London: Prentice Hall Inc.

Cohen, L., Manion, L., \& Morrison, K. (2007).Research methods in education (6th ed.). Washington, DC: Taylor \& Francis.

Cummins, J. (1979). Cognitive/academic language proficiency, linguistic interdependence, the optimum age question and some other matters. Working Papers on Bilingualism, 19, pp. 121-129.

Darkos, J. (2005). Ideas for developing a personal EFL teaching curriculum. The Internet TESL Journal, XI(3).

Foroozandeh, E., Riazi, A., \&Sadighi, F. (2008).TEFL program evaluation at master's level in Iran. TELL, 2 (6), pp. 71-100.

GAO (US General Accounting Office) (1998).Performance measurement and evaluation: Definitions and relationships. Retrieved May, 2013 from http://www.gao.gov/special.pubs/gg98026.pdf

Gatehouse, K. (1998). Key issues in English for Specific Purposes (ESP) curriculum development. The Internet TESL Journal, VII (10). 
Halim Ulaş, A., Epcacan, C., \&Kocak, B. (2011).Assessment of the curriculum of Turkish language teaching in the 2 nd grade of primary education in terms of critical thinking skills.Procedia- Social and Behavioral Sciences, 31, pp. $369-375$.

Henning, G. (1987). A guide to language testing: development, evaluation, research.Newbury: House.

Jones, G. (1990). ESP textbooks: Do they really exist?.English for Specific Purposes, 9, pp. 89-93

Kariminia, A. \& Salehizadeh, S. (2007). Communication strategies: English language departments in Iran. Iranian Journal of Language Studies, 1(4), 287-300.

Kariminia, A. \& Mahjoobi, M. (2013). Individual differences and quality of translation: A personality-based perspective . Psychology of Language and Communication, 17(1), 38-64.

Keyvanfar, A. (1999). The undergraduate English translation major in Iran: A program evaluation.Unpublished doctoral dissertation. Islamic Azad University, Science and Research Branch.

Lindsay, R., Breen, R., \& Jenkins, A. (2010).Academic research and teaching quality: The views of undergraduate and postgraduate students. Studies in Higher Education, 27 (3), pp. 309-327.

McDavid, J.C. \& Hawthorn, L.R.L. (2006).Program evaluation and performance measurement.USA: SAGE Publications.

McNamara, C. (2002). Basic guide to program evaluation. Retrieved May, 2013 from http://www.managementhelp.org/ evaluatn/fnl_eval.htm

Rahmani, N. (2007). On the efficacy of BA translation program in Iran (An evaluation study). Unpublished doctoral dissertation. Islamic Azad University, Science and Research Branch.

Rossi, P.H., Lipsey, M.W. \& Freeman, H.E. (2004).Evaluation: a systematic approach. Retrieved May 2013, from http://en.wikipedia.org/wiki/Program_evaluation.

Stufflebeam, D.L. (2002). CIPP evaluation model checklist. Retrieved March 2013, from www.wmich.edu/ evalctr/checklists.

Towell, R., \& Tomlinson, P. (1999).Language curriculum development research at university level. Language Teaching Research, 3 (1), pp. 1-32. 


\section{Turkish Abstract}

İran'daki Lisans Programlarında İngilizce Öğretiminin Değerlendirilmesi: Çoklu Bir Vaka Çalışması

$\mathrm{Bu}$ çalışmanın amacı lisans düzeyinde ingilizce derslerinin İslami Azad Üniversitesindeki kalitesini değerlendirmektir. $\mathrm{Bu}$ amaçla küme örnekleme yöntemi kullanılarak 5 fakülte seçilmiştir. Seçilen beş fakülteden, 20 birinci sınıf öğrencisi rassal olarak katılımcı olarak seçilmiştir. Öğrencilere ek olarak gelişigüzel örnekleme yöntemiyle 5 öğretim üyesi seçilmiştir. Stufflebeam'in (2002) CIPP modeli kullanılarak veriler araştırmacı tarafindan oluşturulan bir ölçekle toplanmıştır. Bu model değerlendirmenin dört temel segmentini bağlam, girdi, süreç ve ürün bir araya getirmiştir. Öğrencilerin verdikleri cevaplara göre çalışmada sonuç olarak öğrencilerin çoğunluğu programın kendisiyle birlikte öğretim materyallerinin de revise edilmesi gerektiğini belirtmişlerdir. Öğrenciler ayrıca öğrenme stratejilerinin daha yoğunlaştırılmış olması gerektiğini ortaya koymuşlardır. Ayrıca, öğrenciler öğretim üyelerinin de özelleştirilmiş dersleri yürütmeye odaklanmaları gerektiğini düşünmektedirler. Yarı-yapılandırılmış görüşme sonuçları da öğretim üyelerinin bu programlarda önemli bir reform yapılması gerektiğine işaret ettiklerini göstermiştir. Görüşülen kişiler ayrıca geçen on yıllarda genellikle kullanılan pedagojik yaklaşımların üstesinden gelinmesi gereken eksikleri olduğunu göstermiştir.

Anahtar Kelimeler: yabancı dil olarak İngilizce öğretimi, müfredat tasarlama, CIPP modeli, program değerlendirme, lisans

\section{French Abstract}

\section{Une Évaluation du Programme de TEFL en Licence en Iran : une Multi-étude-de-cas}

Le but de cette étude est d'évaluer la qualité d'Université Azad Islamique TEFL le programme à B.A. Niveau (en licence) en Iran. Pour faire ainsi, cinq branches IAU ont été choisies par l'échantillonnage de groupe. Dans chaque branche choisie, vingt étudiants seniors ont été aléatoirement échantillonnés comme les participants de l'étude. En plus des étudiants, cinq professeurs qui ont été choisis par l'échantillonnage accidentel ont participé à cette étude, aussi. En utilisant Stufflebeam (2002) le modèle de CIPP, les données a été rassemblé par un questionnaire fait de chercheur. Ce modèle incorpore quatre segments principaux incluant les évaluations de contexte, l'apport, le processus et le produit. En ce qui concerne les réponses des étudiants, les résultats de l'étude ont révélé que la plupart des étudiants ont reconnu que les matériels pédagogiques ont dû être révisés avec le programme de TEFL lui-même. Les étudiants ont aussi cru que l'apprentissage de stratégies doit être plus concentré sur. De plus, ils ont cru que les professeurs doivent se concentrer sur des cours spécifiques enseignants. En ce qui concerne les résultats des entretiens de semi-structures, les professeurs ont surtout indiqué que la réforme considérable doit être mise en œuvre dans le design de programme d'études TEFL. Les interviewés ont aussi déclaré que les approches pédagogiques généralement utilisées au cours des décennies passées subies des défauts qui doivent être surmontés. 
Mots Clés: TEFL, le design de programme d'études, CIPP le modele, programme l'évaluation, l'étudiant en licence

\section{Arabic Abstract}

تقييم البرنامج TEFLالجامعية في إيران :دراسة متعدد حالة

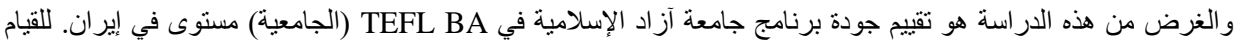

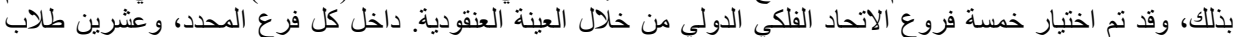

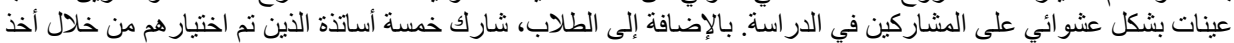

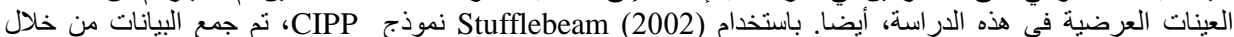

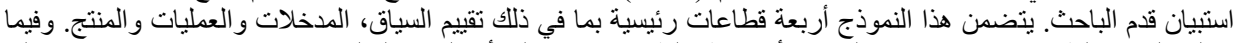

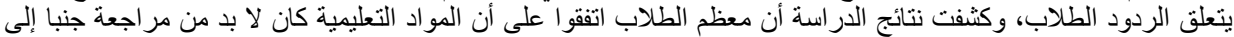

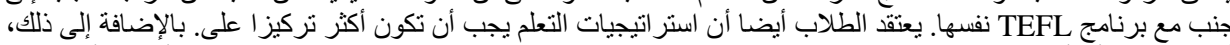

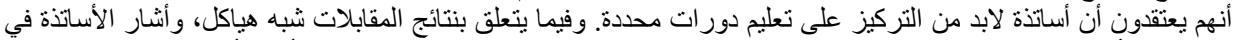

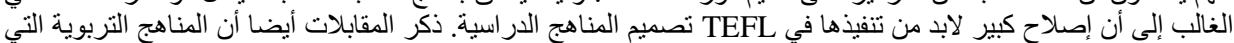

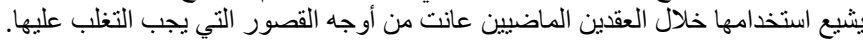

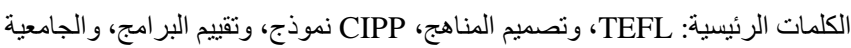

